\title{
Artelogie
}

artelogie Recherche sur les arts, le patrimoine et la littérature de l'Amérique latine

$6 \mid 2014$

Horizons et dispositifs des arts plastiques des pays du Río de la Plata (XXe siècle)

\section{Proyecciones discursivas y expositivas sobre las artes visuales de Argentina en los albores de la globalización}

Viviana Usubiaga

\section{OpenEdition}

\section{Journals}

Edición electrónica

URL: http://journals.openedition.org/artelogie/1355

DOI: 10.4000/artelogie. 1355

ISSN: 2115-6395

Editor

Association ESCAL

Referencia electrónica

Viviana Usubiaga, "Proyecciones discursivas y expositivas sobre las artes visuales de Argentina en los albores de la globalización », Artelogie [En línea], 6 | 2014, Publicado el 24 junio 2014, consultado el 02 mayo 2019. URL : http://journals.openedition.org/artelogie/1355; DOI : 10.4000/artelogie.1355

Este documento fue generado automáticamente el 2 mayo 2019.

Association ESCAL 


\title{
Proyecciones discursivas y expositivas sobre las artes visuales de Argentina en los albores de la globalización
}

\author{
Viviana Usubiaga
}

\section{Introducción}

1 El inicio de década de 1980 encontró a los países del Cono Sur de América Latina sumidos en las más crudas dictaduras de su historia del siglo XX. En la Argentina la crisis del régimen militar se desencadenó tras la derrota frente a Gran Bretaña en la Guerra por las Islas Malvinas en 1982. Este acontecimiento aceleró un proceso de transición hacia el restablecimiento de la democracia que, con su llegada a fines de 1983, habilitó el inicio de una larga, dificultosa y aún inacabada reconstrucción política, social y cultural del país.

2 Centrado en aquella década este artículo se ocupa, menos de un estudio de las producciones artísticas tensionadas por el duelo de la dictadura y la vitalidad de la libertad recobrada ${ }^{1}$, que de un análisis de las proyecciones tanto discursivas como expositivas construidas sobre las artes plásticas argentinas en los albores de la mentada globalización. A través de un recorrido sinuoso por una serie de exposiciones y textos críticos que propiciaron debates sobre el deber ser del arte argentino y de la región, se busca revisar y complejizar las discusiones que a menudo se limitan a señalar y naturalizar la mirada sobre la producción artística de estas latitudes en encrucijadas de carácter polar tales como centro-periferia, original-copia o identidad nacionalmimetismo internacional. La hipótesis del trabajo sostiene que durante los años ochenta y ante la reapertura cultural tras las crisis de las dictaduras en la región existieron no solo acaloradas polémicas sobre las características de un arte genuino sino el despliegue de diferentes posicionamientos frente a las poéticas internacionalistas que desembarcaban desde Europa y Norteamérica. Lejos de una recepción pasiva de lineamientos estéticos 
foráneos es posible verificar, por un lado, la crítica paródica que dejaba ver sus limitaciones aun cuando ciertos operadores del arte optaron por una mala traducción de términos y su aplicación desproblematizada. Por el otro, se constata la presentación de estrategias de circulación y visibilidad de producciones artísticas y teóricas que denotan la existencia de horizontes conceptuales alternativos a modelos restrictivos. Asimismo, se comprueba el establecimiento de otras condiciones de producción que darían paso a una nueva etapa para la historiografía crítica desde y sobre América Latina.

3 A través del análisis de una selección de episodios ocurridos en el campo artístico me ocuparé de la conflictiva recepción de la Transvanguardia que constituyó sin duda un límite interpretativo para el arte argentino y latinoamericano de entonces. Examinaré la organización de exposiciones locales e internacionales que propiciaban paródicas resistencias por parte de los artistas; de la participación y representación de diferentes posturas visibles en el desarrollo de las Jornadas Internacionales de la Crítica en Buenos Aires y de la Bienal de San Pablo como escenarios de acalorados debates. Por último, abordaré la conformación del Grupo Periferia que enfatizó la marginalidad como virtud creativa hacia el final de la década. El trabajo reconstruye la trama cultural de un momento clave para la reapertura y el fortalecimiento de una red de contactos artísticos e intelectuales que permitió desestabilizar concepciones sobre el arte argentino y latinoamericano y propiciar la elaboración de una nueva historiografía sobre el arte de América Latina al que este artículo busca contribuir.

\section{Entre la asimilación y la disidencia, la parodia crítica}

4 En 1981 el teórico del arte italiano Achille Bonito Oliva fue invitado a Buenos Aires a participar en las IV Jornadas Internacionales de la Crítica ${ }^{2}$, organizadas por la Asociación Argentina de Críticos del Arte (en adelante AACA), presidida por el empresario y crítico Jorge Glusberg. Desde entonces Bonito Oliva realizó varias visitas al país durante las cuales dio conferencias en el Centro de Arte y Comunicación (CAYC) en las que difundía su concepción del arte de la Transvanguardia.

5 En un artículo publicado en la revista Flash Art en 1979 (BONITO OLIVA, 1979: 17-20) el crítico había introducido este concepto para definir la producción de un grupo de artistas italianos encabezado por Sandro Chia, Francesco Clemente, Enzo Cucchi, Nicola de Maria y Mimmo Paladino. Al año siguiente presentó a los artistas mencionados en el Aperto 80, un sector creado dentro de la Bienal de Venecia para la exhibición de figuras emergentes, y publicó un libro de gran difusión, titulado La Transvanguardia Italiana (BONITO OLIVA, 1980). En este volumen Bonito Oliva desarrolló su teoría que proponía superar la idea de progreso que se hallaba en crisis para pensar el arte contemporáneo "más allá de la vanguardia". "El arte finalmente retorna a sus motivos internos, a las razones constitutivas de su operar", comenzaba postulando el ensayo. Según el crítico, hasta los años setenta en el arte de vanguardia había operado el darwinismo lingüístico, es decir, subyacía una concepción evolucionista de la cultura. En cambio, el arte de la Transvanguardia se liberaba de la coerción de lo nuevo y del seguimiento de genealogías puristas ; subrayaba una nueva subjetividad del artista tanto en el placer de sus pulsiones e imaginarios privados como en el reencuentro con la materia de la pintura que superaba el primado del “ ideologismo del pauperismo y la tautología del arte conceptual” (BONITO OLIVA, 1982:29). Junto al hedonismo, el nomadismo era la actitud básica del artista transvanguardista, entendida como "posibilidad de transitar libremente dentro de todos los territorios sin ningún 
impedimento." La inestabilidad comenzaba a manifestarse en el carácter transitorio del estilo, o más bien, en una deriva estilística que no reconocía necesariamente la primacía de un punto de vista teórico general y así ponía de manifiesto la caída de todos los sistemas dogmáticos (científicos, políticos, religiosos, etc.). El autor encontró en esta concepción una sensibilidad afín al Manierismo del siglo XVI, cuando tras la crisis epistemológica que siguió al esplendor del Renacimiento y su centralidad en la razón, los artistas volvieron a mirar el pasado en forma oblicua y ambigua, para cuestionarlo en lugar de imitarlo, para citar sus modelos fragmentándolos y contaminándolos con otros (GUASCH, 1997: 316-317). Apelaba así al encuentro de la piccola emozione dell' arte y a las oscilaciones entre lo trágico y lo cómico en detrimento de una "dimensión dramáticamente romántica" presente en las prácticas artísticas precedentes. En síntesis, nomadismo, transitoriedad, eclecticismo, nihilismo activo, hedonismo y apropiación fueron los ejes claves que definieron por anticipado la obra "neomanierista" que el fenómeno transvanguardista desarrollaría en los años ochenta.

6 Transvanguardia: Italia/América fue una de las primeras exposiciones que encumbraron a la nueva corriente. Llevada a cabo en la ciudad de Módena en marzo de 1982, tuvo carácter internacional y transatlántico al incluir junto a los integrantes primigenios del grupo italiano a una serie de artistas norteamericanos: Jean Michel Basquiat, David Deutsch, David Salle, Julian Schnabel y Robert Zakanitch, a quienes el curador aunaba por su "visión ecléctica" dentro de los desvíos de la imagen de lo "figurable" que superaba las divisiones entre la abstracción y la figuración. Un punto central en sus planteos era concebir un internacionalismo en el arte que recuperara al mismo tiempo el genuis loci que habitaba en el propio territorio antropológico y cultural de cada artista ; es decir, que las obras de sus integrantes conservarían el "espíritu del lugar" de origen que lo distinguiría y pondría a resguardo de los riesgos de la uniformidad de lenguajes. No obstante, veremos cómo con el correr de los años la misma campaña de difusión mundial de la tendencia provocó en un mediano plazo no sólo la homologación en la apariencia de ciertas obras sino la multiplicación monótona e indiferenciada de las lecturas y discursos críticos sobre la producción de los años ochenta. En el caso argentino, justamente la falta de un detenimiento sobre las diferencias sustanciales en las circunstancias materiales y espirituales del lugar, sumada a las aspiraciones de posicionar la producción local -de artistas y gestores- en diálogo con los centros artísticos sin una estrategia efectiva y diferenciadora, fue lo que contribuyó a sesgar la mirada sobre la densidad de los fenómenos locales. No obstante, como veremos, contemporáneamente al desembarco del fenómeno de la Transvanguardia y de las redes de contacto directo que creó Bonito Oliva con el medio artístico argentino, se alzaron voces muy críticas que discutieron y objetaron desde un comienzo no sólo aquellas concepciones -como sucedía en otras tantas partes del mundo y en particular desde la revista norteamericana October ${ }^{3}$ - sino la función que debía asumir la crítica cultural por entonces. Por su parte, algunos artistas produjeron acciones de desajuste en la aplicación de conceptos ajenos al contexto de sus propias producciones.

7 En efecto, el primer número de El Porteño -una influyente revista político-cultural aparecida en Buenos Aires a fines de la dictadura- dedicó una nota titulada "¿Para qué sirven los críticos ?" (ESTENSSORO, 1982: 42-43) en la que se partía de aquellas Jornadas Internacionales para poner en cuestión las acciones de la crítica que se estaban llevando adelante en el ámbito local. Se trató de una corrosiva reseña sobre las sesiones organizadas por la AACA que problematizaba sobre la función del crítico como mediador 
ante el público a través de las opiniones de artistas como Víctor Grippo, Gabriel Messil, Alfredo Prior, Florencio Méndez Casariego. Se plantearon las desventajas para un eficaz desarrollo de la actividad crítica en el país por la falta de un mercado que incentivase un trabajo sostenido sobre la producción. La intervención de Grippo cerraba la nota afirmando que una de las tareas que debían emprender los críticos argentinos era la historización del arte local. "Acá hay una falta o ausencia de memoria histórica-que se da en otros campos también-. No se registra nada, hay como un caos en ese sentido, no se archiva nada en una suerte de memoria cultural. Para mí esto es grave. Existe un tremendo olvido", sostuvo el artista.

8 A pesar de la evidencia de la crisis de criticidad -o por esta misma razón- parte del circuito porteño de inmediato se hizo eco de los programas estéticos que los curadores europeos sostenían. Se organizaron exposiciones que calcaban sus planteos en versiones vernáculas y se incorporó el vocabulario utilizado por aquellos curadores en las reseñas críticas sobre la producción local. Por su parte, los artistas argentinos no desconocían las "tendencias" del arte internacional, incluso algunos de ellos tuvieron experiencias directas con esas producciones. Remo Bianchedi, por ejemplo, había viajado a Alemania tras la obtención de la beca "Albert Dürer" del D.A.A.D. (Deutscher Akademischer Austausch Dienst - Servicio Alemán de Intercambio Académico) que le permitió estudiar Diseño Gráfico y Comunicación Visual en la Escuela Superior de Artes de Kassel, ciudad en la que permaneció entre 1977 y 1981 y se convirtió en discípulo de Joseph Beuys. Por su parte, el joven Guillermo Kuitca, voló a fines de 1980 a Europa en un viaje que lo llevaría hasta Wuppertal, siguiendo a la compañía de Pina Bausch que había conocido en Buenos Aires durante las presentaciones de los espectáculos de la coreógrafa alemana, cuyas imágenes tanto influyeron en su producción posterior. A comienzos de 1981 Kuitca se hallaba en Londres y tuvo oportunidad de visitar la exposición New Spirit in Painting en la Royal Academy curada por Christos Joachimides, Norman Rosenthal y Nicolas Serota; exposición en la que se encontraron en escena los transvanguardistas italianos con los pintores alemanes que cultivaban el neoexpresionismo, conocidos como "los nuevos salvajes". Kuitca reconoce que lo que vio en ese entonces recontextualizaba su propia obra de alguna manera, aún cuando no se sentía identificado con "esa pintura tan expresionista" y "no comulgaba con esa explosión pictórica" (Kuitca en SPERANZA, 1998 : 20). De todos modos, esto no significó que los artistas argentinos comenzaran una copia sistemática de sus imágenes, así como la crítica hiciera de los discursos. En todo caso, se nutrieron de ciertas actitudes de los artistas que actuaban en los centros (de la insistencia en trabajar en el medio pictórico articulándolo con otros lenguajes y materiales extraartísticos ; o de una despreocupación por la "calidad" del objeto acabado) pero sus resultados estuvieron siempre atravesados por una realidad muy distinta de la de Europa o Nueva York. Sostengo que la propagación de los discursos de la Transvanguardia y del neoexpresionismo, actuó más bien como un contexto legitimador de las propias búsquedas y transformaciones que los creadores venían haciendo. Un legendario artista como Juan Pablo Renzi, contemporáneamente a un nuevo cambio en su lenguaje desde cierto hiperrealismo a una "pintura romántica y más irracional", escribió : "Las teorías en boga (en general los artistas nos nutrimos de ellas) son como los objetos, substanciales y materiales que utilizamos, aun cuando no participemos de sus principios. Creo que para todo artista, hay una licencia que le permite usar arbitrariamente cualquier idea" (1986:16).

9 Sin tomar en cuenta los debates que se habían despertado, aquellos modelos discursivos fueron adoptados por algunos críticos del arte de la ciudad de Buenos Aires casi sin 
cuestionamientos o pasándolos por alto en sus apreciaciones. Desde esta perspectiva, Jorge Glusberg se dedicó al intento de alinear con la Transvanguardia a un grupo de artistas argentinos. Así fue como organizó una serie de exposiciones bajo el nombre de $L a$ Nueva Imagen. Aseguraba que su proyecto curatorial "justifica de alguna forma lo que está sucediendo, contemporáneamente, en los grandes centros artísticos internacionales. A través de ellos es posible ver cómo nuestros artistas utilizan los mismos lenguajes que europeos, norteamericanos $y$ australianos, y están -indiscutiblemente- en un horario internacional" (GLUSBERG, 1982). En otras palabras, este operador del arte adhirió tempranamente a la postulación de la Transvanguardia como un fenómeno "casi universal" extensible a sus correlatos en la llamada pintura salvaje o la nueva imagen. Este último es el mote que adoptó para etiquetar la producción disímil de artistas que, con circunstanciales incorporaciones o exclusiones, exhibió bajo su planteo curatorial explicitado en un prólogo que se reiteró a lo largo de más de una década. El término 'Nueva Imagen' parece haber sido literalmente traducido del título New Image Painting, nombre bajo el cual Richard Marshall presentó una exposición en el Whitney Museum of American Art de Nueva York a fines de 1978. En ella el curador seleccionó a los artistas Nicholas Africano, Jennifer Bartlett, Denise Green, Michael Hurson, Neil Jenney, Lois Lane, Robert Moskowitz, Susan Rothenberg, David True y Joe Zucker, cuyo casi único denominador en común era que representaban imágenes reconocibles en diálogos ambiguos con la abstracción. Desde la libre manipulación del medio pictórico, estos artistas fueron presentados como alternativa a la idea de caducidad de la pintura patentada por los defensores del arte conceptual.

Si bien algunos de los rasgos de la New Image pueden identificarse en la pintura argentina, la construcción discursiva de Jorge Glusberg se emparentó más específicamente con la producción teórica de Bonito Oliva que con aquel contemporáneo y homónimo proyecto curatorial norteamericano. No obstante, puede señalarse una paradoja en la elección del término "nueva" para nomenclar la producción más reciente de los artistas argentinos cuando justamente las implicancias del concepto de lo "nuevo" era uno de los puntos centrales que rechazaba la tendencia Transvanguardista. El vaciamiento de criticidad de la noción de novedad se fue acrecentando con el curso de los años durante los cuales el curador argentino presentó la Nueva Imagen una y otra vez sin modificar o ajustar su discursividad textual con la que acompañaba el desarrollo de una producción pictórica fluctuante. Con las "nuevas" imágenes de los artistas que fueron integrando cada una de las exposiciones de la Nueva Imagen, el discurso sobre ellas no se "renovaba". con lo cual la distancia entre las imágenes y las palabras se ampliaba.

La primera edición de La Nueva Imagen realizada por Glusberg, se llevó a cabo en la galería del Buen Ayre en noviembre de 1982. La selección de obras correspondió a artistas de diferentes orígenes, lenguajes y generaciones tales como: Antonio Berni, los cuatro protagonistas de la Nueva Figuración de la década de 1960 (Ernesto Deira, Jorge De la Vega, Rómulo Macció y Luis Felipe Noé), el otrora informalista Kenneth Kemble, los más jóvenes representantes como Pablo Bobbio, Rafael Bueno, Juan José Cambre, Ana Eckell, Guillermo Kuitca y Osvaldo Monzo, entre varios otros. Ese mismo año, este amplio conjunto de creadores, con la inclusión de Hilda Paz, quedó amalgamado en el capítulo "La Nueva Imagen en Latinoamérica" (GLUSBERG, 1982: 291-301) del libro editado por Bonito Oliva, Transavant-garde Internacional. En este artículo Glusberg tejió una cuestionable red de filiaciones de los artistas contemporáneos argentinos que promovía. Estableció genealogías tan abarcativas como improbables. Desde la enunciación de un 
eclecticismo reinante rescataba referentes disímiles que van "de Bacon al Grupo CoBra, de los muralistas mejicanos al maestro argentino Antonio Berni". El otro antecedente de la Nueva Imagen en Argentina apuntaba al grupo de la Nueva Figuración mencionado anteriormente. De ahí la inclusión en las exposiciones de obras de estos artistas de aquella época aunque éstos permanecieran activos -menos de la Vega fallecido en agosto de 1971- con nueva producción. El propio Noé ha afirmado, tiempo después, que "la pintura salvaje tuvo un peso raudo y efímero. Sirvió también, para reivindicar a artistas o grupos locales a los que se consideraba precursores de la tendencia en el medio. Así ocurrió con el grupo de la nueva figuración. Todo esto rápidamente pasó. Quiso actuar como una vanguardia a destiempo, sin poder lograrlo ya que la época de las vanguardias había muerto en la etapa preconceptual" (NOÉ, 1993 : 241).

Parecía más difícil de justificar en las muestras organizadas por Glusberg, la inclusión de obras de Luis Wells y Kenneth Kemble. Así se cumplía, al igual que en las exposiciones internacionales, con el armado de una genealogía que articulaba el movimiento que emergía con protagonistas de la "vanguardia" del pasado. En este caso se consideraba más su continuación que una ruptura en los neoexpresionismos contemporáneos. En esto punto parecía diferenciarse de lo planteado por las poéticas internacionales, a la vez que tornaba más imprecisa la idea de vanguardia que se pretendía "trans-pasar". Por lo tanto, cada vez que se extrapolaban los modelos sin los ajustes necesarios se tornaba evidente la inestabilidad de las concepciones de las que se intentaba aferrar.

Por entonces, en la escena porteña Bonito Oliva se había convertido en un interlocutor directo y dilecto de la crítica de artes visuales en Buenos Aires.

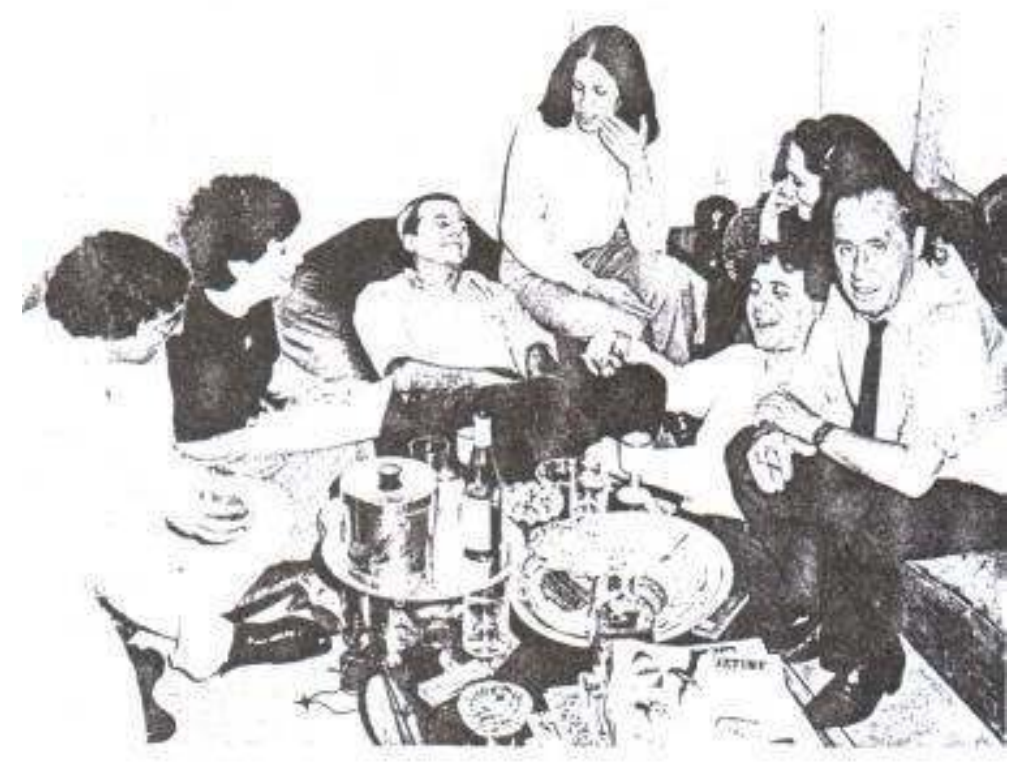

Mientras sus lecciones eran aprendidas y literalmente aprehendidas por la crítica, pronto la parodia como procedimiento estratégico en las prácticas culturales se hizo presente. Marcelo Pacheco señala: "La parodia implica siempre un movimiento doble, de ida y vuelta: la construcción de un segundo texto que conserva en su tramado rastros de un texto original, un texto preexistente que se convierte en texto modelo ; un texto parodizante y un texto parodiado. El gesto paródico conecta dos textos, fabrica la circulación de sentidos en el espacio que separa y que une a 
un Texto A y a un Texto B, segundo pero mandante porque es el punto de inicio de la acción" (PACHECO, 1999: 91).

Es elocuente en este sentido lo ocurrido en la organización de la muestra La Anavanguardia organizada por Carlos Espartaco en el Estudio Giesso en 1982. Este crítico argentino se inspiró en la Transvanguardia italiana para equiparar la obra de los artistas Rafael Bueno, Kuitca, Prior, Armando Rearte y Enrique Ubertone con la de los italianos.

Afiche de la exposición La Anavanguardia, 1982, Espacio Giesso

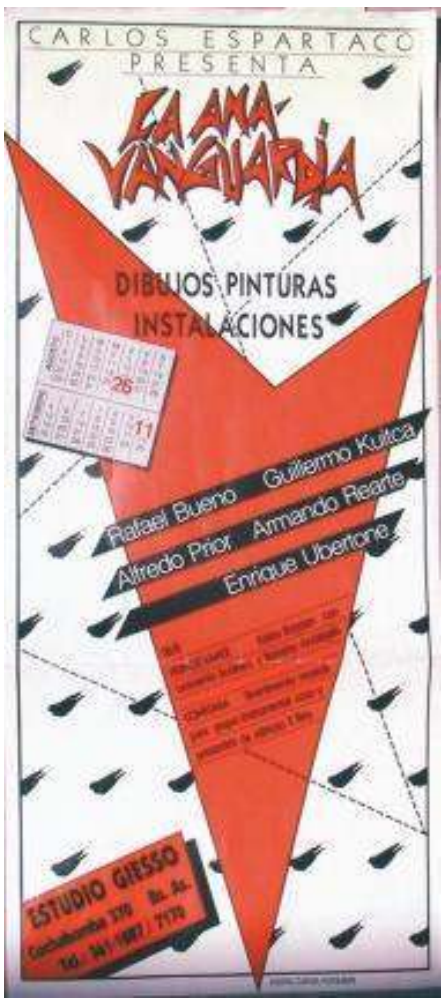

Aun cuando en el prólogo de la muestra retomó la tesis transvanguardista, la estrategia de diferenciación de Espartaco fue la alteración del prefijo "trans" por el de "ana" y la aclaración de que éste no indicaba que la producción de estos artistas se colocara por fuera del concepto de vanguardia, sino "porque pone en duda el optimismo historicista de esta última, ínsito en la idea de progreso y evolución del lenguaje. Es decir, que los artistas de la anavanguardia no se oponen frontalmente a nada sino que ubican el acento en las travesías de la imagen, en la diseminación de los conceptos pictóricos y en una fuerte adhesión a la manualidad y las particularidades" (ESPARTACO, 1982). La reenunciación de lo que en términos originales de Bonito Oliva se trataba de "crisis de la mentalidad darwinista y evolucionista de la vanguardia", reencuentro del placer de tener las manos en la pintura y "la posibilidad de recuperar la posesión de una subjetividad", quedó subsumida en un inocuo corrimiento de prefijos y en una adaptación de las apreciaciones vertidas por Bonito Oliva para sus artistas a las producciones vernáculas.

En un gesto de insolencia, paródico en tanto imitaba para burlarse de la naturaleza del amaneramiento sobre las categorías, los artistas que participaron en la muestra redoblaron la adaptación terminológica llamándola La Juanavanguardia: antes de que entrara en imprenta reemplazaron el prefijo "ana" por "juana" en la última mención en el catálogo. Razón por la cual el texto de Espartaco finalmente concluía: "La obra de estos 
cinco artistas filiados en el concepto de juanavanguardia se orienta hacia instrumentos más ligados a la tradición del arte y nace de una emergencia histórica que no permite hacerse demasiadas ilusiones más allá de los límites del cuadro, de su condición específica, colocando su acento en el rescate de la subjetividad y la colectivización del significante artístico. La fuerza mítica del arte pierde su tensión monolítica a favor de una imagen intensa y decontractada, cambiante a través de la superficie del estilo y de los verdaderos lenguajes recuperados".

Sobre aquel paródico cambio, Prior ha señalado que "La Juanavanguardia nos parecía [algo más] latinoamericano, una especie de guerrillera mejicana, zapatista” (PRIOR, 1999 : 4). Para Kuitca fue como una forma particular de "resistencia", "como una manera de posicionarnos frente a ese modo casi esquemático de reunir a este grupo de artistas en referencia a otros grupos de artistas" (Kuitca en SHAW, 1998 : 152-153).

Los creadores sumaban oportunidades para mostrar sus obras y sacaban provecho de la legitimación que en el medio local suponía la construcción de correlatos con los artistas internacionales, aunque las desestimaran. Cuando Bonito Oliva vino a Buenos Aires en 1981 visitó la muestra curada por Espartaco en la Galería Artemúltiple, dirigida por Gabriel Levinas, que formó parte de las actividades de las Jornadas Internacionales de la Crítica. La Joven Generación, así se llamó la exposición -tanto menos pretenciosa y más independiente de teorías ad hoc que la configuración de La Anavanguardia- reunía genuinamente los trabajos recientes de los ya mencionados Cambre, Kuitca, Prior, Rearte y Monzo, junto a otros artistas emergentes como Carlos Kusnir, Eduardo Médici, Máximo Okner y Claudia Zemborain, entre otros.

En esa ocasión el crítico italiano se interesó en un dibujo de Kuitca que contenía tacitas y le habló al respecto. El artista argentino recuerda que en ese momento, con sólo veinte años de edad, se lamentó de que no lo hubiera conocido antes, pensando que había perdido la oportunidad de formar parte de sus curadurías internacionales y del boom que se gestaba. No obstante, en la actualidad se cree afortunado porque aquellas expectativas no se cumplieran. ${ }^{5}$ Entre sus dibujos de la época, figura uno en el que sobre un cuadrado superpuesto a una forma oval casi borrada, se lee la pregunta "¿Qué es esto?"; arriesga una especie de doble respuesta en forma cruzada : "Esto es una forma. Esto un contenido" y por debajo aparece la frase “¡Vamos a preguntarle a los colegas italianos!”. La pequeña obra ironizaba sobre la pretendida situación para el arte contemporáneo de abandonar lo conceptual para entregarse al significante y privilegiarlo por sobre el significado. En el medio porteño, todo indicaba que la clave para superar los dilemas acerca de la crisis en la representación parecía encontrarse en las manos de los "colegas italianos". 


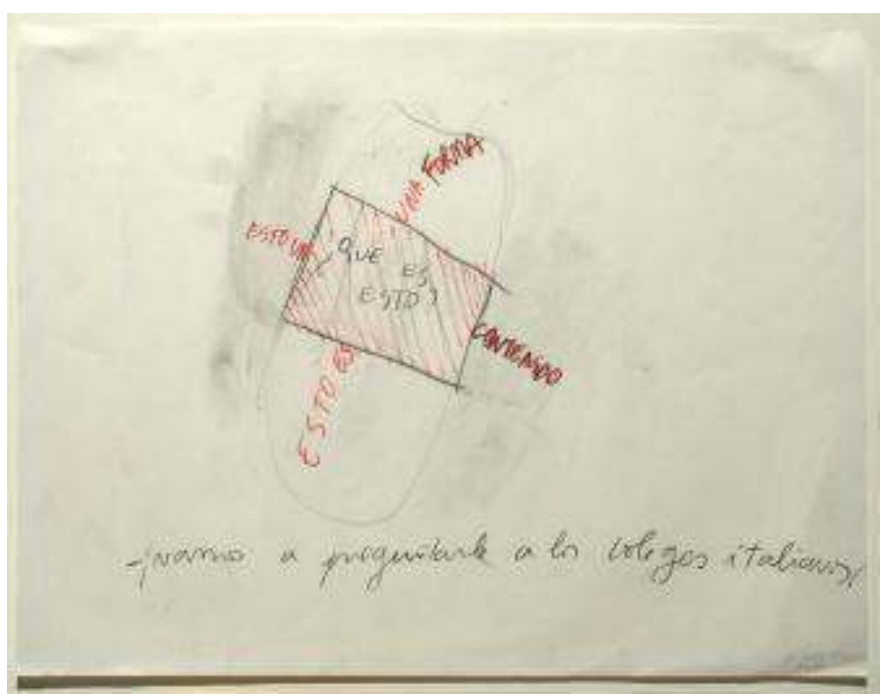

lápiz sobre papel. Cortesía del artista

La tesis de Bonito Oliva continuó propagándose en estas tierras, no sólo por sus conferencias sino también a través de la publicación de sus textos. La editorial RosenbergRita editó su libro en español, traducido precisamente por Carlos Espartaco. El libro contó con un prólogo del influyente crítico de la década de 1960, Jorge Romero Brest. Allí alzó su voz y sin disimular sus reticencias sobre la propuesta de Bonito Oliva señaló sus disidencias: "En primer lugar, que el autor se refiere al proceso de la pintura de Italia, donde precisamente la vanguardia no fue tan osada como las vanguardias (en plural) de otros países, a las que compara permanentemente con aquélla." Romero Brest comenzaba poniendo en duda que el llamado arte povera hubiera funcionado como una vanguardia propiamente dicha. En segundo término, se mostraba desconcertado por el fervor del autor respecto de la Transvanguardia -“ ¿por ser italiana ?", se preguntaba- a partir de un número tan reducido de pintores. Y continuaba : "en cuanto se abandona el texto hiperbólico y se miran los cuadros reproducidos, el desfasaje entre la teoría y la práctica es total. En vez de percibir las virtudes exaltadas, uno se encuentra con imágenes parecidas a las que crearon las vanguardias anatematizadas, ni siquiera las más fecundas, viejos recursos conocidos." De alguna manera, el veterano crítico de arte, apuntaba a las diferentes experiencias de vanguardia (o neovanguardias) existentes entonces en los horizontes de Italia o Argentina. Diferencias sustanciales que los críticos seguidores del transvanguardismo pasaban por alto en sus miméticas apreciaciones, menos sobre las imágenes que acerca de las propias elucubraciones, que ellos proyectaban sobre las obras.

En el primer número de la revista Arte Sur. Cuadernos de artes visuales dirigida por Alberto Collazo se incluyó la publicación del prólogo del catálogo de la exposición Italia. La Transvanguardia realizada en Madrid en 1983 (BONITO OLIVA, 1984). El número siguiente registró una breve polémica donde el crítico Abraham Haber y un pintor en la línea de los realismos como Héctor Giuffré discutían las premisas del programa transvanguardista. Haber recurrió a la opinión de Yamandú Canosa, un pintor uruguayo residente en Barcelona y que se hallaba en Buenos Aires realizando una exposición. Canosa esgrimía que la Transvanguadia italiana era un concepto que no podía extenderse a otros países porque era un fenómeno exclusivamente italiano, así como el neoexpresionismo lo era de 
Alemania. Señaló acertadamente que: "En realidad se utilizan diversos nombres para un fenómeno similar. Pero no hay que confundir : el fenómeno se llama Post-modernismo, así se dice de él en España, y la transvanguardia es su manifestación en Italia. No hay derecho a extender este último nombre en forma universal puesto que si bien hay una actitud común en todos los países europeos, tienen historias distintas, diferencias nacionales y un paisaje propio que el arte recoge $y$ tiene en cuenta. [...] No hay que confundir el género con la especie. Y la transvanguardia es una especie del género Postmodernismo, de lo contrario entramos en un entrevero sin sentido" (Canosa en HABER, $1985: 42$ ).

En la misma sintonía, Haber alertaba sobre el lugar de subordinación en el que quedaban las producciones de los países americanos al aceptar una vez más la norma europea y manifestarse como un subproducto de ella. "En Argentina la influencia europea fue y es poderosa. Las ideas de Bonito Oliva sobre lo nacional en el arte, que son europeas y por lo tanto poderosas, pueden influir sobre nuestros artistas y efectivamente he visto, últimamente, un avance de lo nacional en las distintas manifestaciones del arte. Pero pienso que en algunos casos el artista hace arte nacional, porque en Europa se hace arte nacional. [...] Así se daría el paradójico caso de que el arte nacional puede ser también el efecto de la colonización cultural europea". Terminaba su comentario refiriendo al paralelo que establecía Bonito Oliva entre la situación de agotamiento contemporáneo con la crisis planteada por el manierismo del siglo XVI. Para ello recurría al pensamiento de Arnold Hauser cuando sugería que la disolución de los ideales renacentistas y la unión de oposiciones aparentemente irreconciliables del manierismo continuaban vigente hasta nuestros días y en ese sentido, los contactos entre el manierismo y el posmodernismo se hacían evidentes.

Por su parte Giuffré discutió punto por punto el artículo de Bonito Oliva, casi reconstruyendo un diálogo imaginario en el armado de su intervención. Partía de la definición de linealidad de la vanguardia para marcar la contradicción del teórico en cuanto a la ruptura de ese modelo a la vez que su propuesta postulaba "otra vanguardia más que procede, tal como siempre, a obsolocer y enterrar a las anteriores. [...] En verdad, la linealidad de la historia que cree Oliva ver quebrada, no se pudo haber quebrado porque jamás ha existido fuera de los manuales escolares. Más vale, sí aceptarle que lo que se ha quebrado es el modelo progresista a través del cual y desde un esquema marxista, muchos, tal vez él, han contemplado a la historia" (GIUFFRÉ, 1985 : 44). De todos modos, el punto más conflictivo que remarcaba el artista era el desconocimiento de la "compleja raigambre tradicional de los distintos pueblos de América, plenos de diversidad de componentes culturales que Oliva niega al poner como únicos determinantes a la raigambre europea y la sucesión de vanguardismos." En efecto, en aquel texto Bonito Oliva sostenía que en el caso de los artistas europeos, la recuperación que realizaban se remontaba a un "tejido cultural que viene de muy lejos", en cambio para los artistas americanos -en realidad se refería a los norteamericanos- el repertorio disponible pertenecía a "un pasado siempre familiar (la tradición de las neovanguardias) y de otro más crítico que encuentra sus raíces en la historia del arte europeo" (BONITO OLIVA, 1984: 42). Siguiendo la lógica del genius loci que habitaba en cada cultura, los artistas que desde los lenguajes contemporáneos reelaboraban los motivos del arte textil de las culturas prehispánicas, es decir, quienes trabajaban en la recuperación de ciertos elementos de la imaginería indígena latinoamericana dentro de un lenguaje abstracto; o quienes seguían las modalidades del constructivismo rioplatense, hubieran debido ser considerados genuinos "transvanguardistas argentinos". Me refiero, por ejemplo, a Alejandro Puente, César Paternosto, Hernán Dompé y Adolfo Nigro, y a los más jóvenes Elizabeth Aro, Alejandro Corujeira, entre otros, cuyas producciones tuvieron una 
fuerte presencia a lo largo de la década de 1980. Pero la construcción de correlatos sobre la noción se realizó de otro modo.

Es posible señalar cómo dentro de la comunidad de críticos las posturas sobre estas construcciones no sólo confrontaban entre sí, sino que en algunos casos se fueron modificando a medida que avanzaba la década. Estos cambios implicaron el apoyo y el subsiguiente alejamiento respecto de ciertos postulados estéticos. Si bien otro crítico como Jorge López Anaya a principios de 1990 cuestionaba a los promotores de la Nueva Imagen y los "conversos" a las ideas de la Transvanguardia (LÓPEZ ANAYA, 1990: 33), durante la década de 1980 había colaborado en difundir las mismas ideas con otro tenor. En un artículo sobre las Jornadas de la Crítica organizadas en septiembre de 1983, al hablar de la muestra de una Nueva Imagen en el Museo Nacional de Bellas Artes, López Anaya señaló que el "neoexpresionismo que ha provocado, entre los artistas jóvenes, un retorno a las prácticas espontáneas, directas, vitales, subjetivas de las poéticas existenciales" (LÓPEZ ANAYA, $1983: 14)$.

Tapa del catálogo de la exposición La Nueva Imagen, Museo Nacional de Bellas Artes de Buenos Aires, 1983.

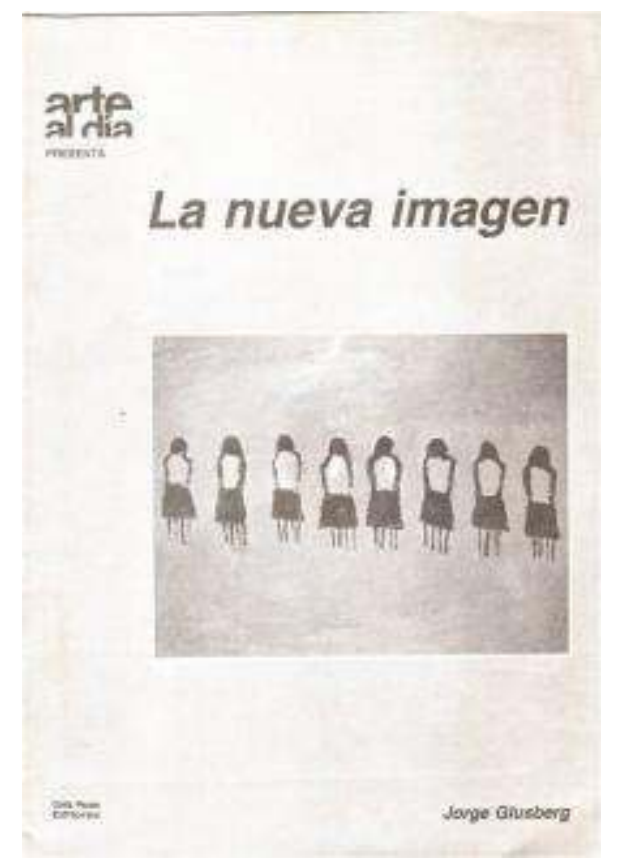

En ese momento, aceptaba la inclusión en "forma simbólica" de obras de los artistas de la Nueva Figuración de 1960 junto a los más jóvenes. Sin embargo, años más tarde hizo explícitos los intereses que movían a Jorge Glusberg para legitimar la implementación de los conceptos de la Nueva Imagen a través de lo que en esta ocasión denomina "los pretendidos antecedentes históricos locales: de la Vega, Noé, Deira, Macció, Berni, Kemble." Focalizaba el cuestionamiento al accionar de sus colegas en los intereses del curador y denunciaba que "La crítica suele ser un discurso que parece actuar en el vacío, sin tener en cuenta las relaciones con aquello de lo que se habla. [...] En todo caso no dan cuenta más que de algunos aspectos parciales, deformados por las redes de complicidades que en nuestro país no son estrictamente comerciales, sino emergentes de ambiciones, de intereses que oscilan entre la perversidad y la inocencia" (1990: 33). 
27 Por su parte, Espartaco, nunca modificó su posición y continuó describiendo la propagación de la Transvanguardia en el territorio como un fenómeno natural, como "un contagio, una contaminación espontánea" (Espartaco en KATZENSTEIN, 1997 : 12) en el hacer de los artistas, sin asumir la fascinación y rechazo que ese modelo había provocado sobre los operadores del arte en aquellos años.

28 A comienzos de 1987 se publicó un artículo escrito por el artista y docente Alfredo Benavidez Bedoya quien, a partir de un episodio ocurrido un año antes, agudizaba la polémica sobre la Transvanguardia. Describió la escena de una nueva conferencia que en enero de 1986 había dado Achille Bonito Oliva en el CAYC de esta manera : "Hacinados en el segundo subsuelo del CAYC, asfixiados de calor e incómodos fueron convocados todos los artistas que dependen del flujo constante del alimento estético que llega de los países centrales, y algunos otros que necesitamos saber qué estrategias prepara ese sector para ensayar en definitiva la defensa más adecuada para los tímidos pero persistentes intentos de crear un arte de características propias. Estaba la plana mayor del proyecto 'internacionalista"' (BENAVIDEZ BEDOYA, 1987 : 32). Esa plana mayor comprendía tanto a artistas como críticos, galeristas y directores de escuelas de artes dispuestos a tomar nota de las nuevas lecciones que el teórico italiano venía a dar. "La noche no defraudó a nadie -continuaba en tono irónico pero severo el relato de Benavidez Bedoya- pues el discurso de Bonito Oliva permite innumerables lecturas o por lo menos tantas como las contradicciones que encierra." La principal y más peligrosa contrariedad que identificaba en sus conceptos era que si por un lado, la propuesta de Bonito Oliva defendía las especificidades de las culturas nacionales y regionales en oposición al centralismo imperante a lo largo del siglo XX -primero desde París y luego desde Nueva York- por el otro, sostenía que esta reiterada defensa del genius loci no era viable en la periferia del mundo, lugar donde recalaba una y otra vez para guiar los pasos de quienes adherían a sus preceptos transvanguardistas. Desde esta perspectiva, los artistas de la periferia debían "practicar la 'cleptomanía' artística, limitándose a reciclar obedientemente los productos genialmente creados por los únicos capaces de hacerlo : los artistas del primer mundo." Indignado por la propuesta, el artista argentino señalaba que : "Bonito Oliva lanzó con todo el cinismo posmodernista un concepto que desde ahora puede ser una definición clara y concisa de la actitud imitadora de muchos de nuestros plásticos: La Cleptomanía, el robo sin delito, la enfermedad apropiadora, la única posibilidad de ser algo, aunque sea un disminuido reflejo. [...] 0 sea que en el caso latinoamericano el genius loci para Bonito Oliva o no existe o es tan poco elegante que es necesario mediante el acto cleptómano apropiarse del genios loci europeo y según sus insistentes insinuaciones prefiriendo el italiano ante cualquier otro." Benavidez Bedoya instaba a dejar de lado esos modelos y a generar una conciencia sobre las posibilidades de creación de los hacedores locales, así como lo habían demostrado los protagonistas de otras ramas artísticas como la literatura, el cine y la música, quienes habían logrado productos admirables sin caer en "tropicalismos ni folklorismos."

Otro de los convidados aquella noche en el CAYC fue Rudy Fuchs -quien había sido el curador responsable de la Documenta 7 de Kassel en 1982. En consonancia con el discurso del italiano, su conferencia apuntó hacia la falta de tradición del arte de Estados Unidos frente a la larga historia de la cultura europea, llegando a calificar su arte como colonial, "fruto de la reelaboración de elementos europeos." Ambos curadores parecían entablar una ofensiva contra la hegemonía norteamericana y en particular la neoyorkina como metrópoli del arte, y en ella sus discursos arrasaban con toda posibilidad de desarrollo, sino en términos de "originalidad" al menos con cualidades sustanciales, para la 
producción artística de estas latitudes. En su argumentación anticolonialista el artista autor de aquella crónica refrescaba la opinión del filósofo español Eduardo Subirats acerca de la última Bienal de San Pablo de 1985, aclarando sarcásticamente que se trataba de la opinión también de un crítico europeo y no de un "trasnochado nacionalista latinoamericano". Subirats había escrito que "La Bienal de San Pablo es la primera bienal del Tercer Mundo y muestra con ello un aspecto esencial de las vanguardias que ni la crítica europea, ni la crítica norteamericana han querido plantear: el papel ejemplar, es decir, normativo que las vanguardias como fenómeno esencialmente metropolitano ejercen sobre las áreas geopolíticas marginales de la tecnocultura moderna. Se trata precisamente de las vanguardias desde el punto de vista de su papel colonizador"' (Subirats en BENAVIDEZ BEDOYA, 1987).

El otro punto central de la conferencia pronunciada por Bonito Oliva fue un conjunto de nuevas consignas para lo que se consideraba la segunda etapa de la Transvanguardia. $\mathrm{Si}$ en sus inicios había primado el gestualismo y el desenfado en el uso del color para alcanzar una figuración visceral en los pintores de la corriente, ahora era necesario "prestar más atención a las cualidades intrínsecas de la obra", es decir, atemperar el color y no descuidar las estructuras compositivas del cuadro. Esto que parecía ser la nueva normativa del mercado del arte traería como consecuencia, según Benavidez Bedoya, una selección natural entre quienes podían hacerlo y "la gran mayoría a los cuales le vino a medida el desenfado formal para ocultar su incapacidad y sus deficiencias de formación." Concluía su reflexión anticipando que los promotores vernáculos de la nueva "cleptomanía" estarían ya preparando sus equipos de reemplazo. Lo cierto es que entre 1986 y 1987 la euforia inicial respecto de estas poéticas internacionales comenzó a aplacarse y las críticas a las mismas, como en este caso, empezaron a circular con mayor frecuencia. Se hablaba de la "Transa-vanguardia" también aquí un juego de palabras que exponía las transacciones, cesiones y en cierto modo la capitulación de algunos frente a la nueva tendencia que se imponía- como un modelo interpretativo de la producción local con el cual, a pesar de las negociaciones de ciertos operadores culturales, no habían logrado internacionalizar el arte argentino. En todo caso, sólo había circulado un grupo de obras de una serie de artistas en particular como extensión de aquello que se hacía en los centros. No obstante, esos mismos artistas demostraban tener una producción que había madurado más allá de lo imitativo de aquellos armados expositivos en los cuales el único beneficio parecía haber sido la visibilidad adquirida en el momento. Un problema sustancial era que las producciones estéticas no habían sido acompañadas por un aparato curatorial y crítico que explotase los sentidos de sus imágenes más allá de ampararse en el sello de La Nueva Imagen. Cabe aquí recordar las controversias surgidas en la Bienal de San Pablo de 1985 por el dispositivo de exhibición creado por la curadora Sheila Leirner llamado la Gran Tela y las idas y vueltas acerca del envío argentino que sumó a la exposición De la Nueva Figuración a la Nueva Imagen curada por Glusberg, la exposición individual de un artista como Alejandro Puente. Es decir, las imágenes presentes en aquella bienal resquebrajaban una anunciada homogeneidad del "fenómeno universal de los neoexpresionismos" al introducir, por ejemplo, ciertas problemáticas regionales que actuaron como contraofensiva de aquellos modelos internacionales. ${ }^{6}$

32 Hacia 1987, sin temerle al uso de la información disponible, enalteciendo la condición de pertenecer a una cultura desplazada del centro del mapa geopolítico y hurgando en la identidad de la marginalidad y sus ventajas, se creó el Grupo Periferia. Fue conformado por Pablo Suárez, Alfredo Prior, Osvaldo Monzo y Duilio Pierri y se presentó en dos 
exposiciones bajo ese nombre en el CAYC ; una inaugurada el 29 de abril de ese mismo año -en la que en lugar de Pierri participó Armando Rearte- y la otra llevada a cabo en mayo de 1988. Monzo recuerda que él junto a Suárez y Prior habían tenido la iniciativa e invitaron en diferentes oportunidades, primero a Rearte, luego a Pierri quien se reconoció como el cuarto integrante. Oscar Bony se sumó luego a su regreso del exilio en Italia en $1988 .^{7}$

Es oportuno recordar que el libro de Beatriz Sarlo Una modernidad periférica. Buenos Aires 1920-1930 (SARLO, 1988), fue publicado precisamente en 1988. El concepto de periferia estaba presente en el horizonte intelectual y debates culturales coetáneos a la aparición del grupo. En 1987 Suárez había sido invitado a formar parte de una exposición llamada Arte de Periferia en el Museo de Arte Moderno de Sydney. La curadora, Dione Holloway aclaraba: "Periferia no se reduce a un hecho geográfico. Se trata de un arte que se produce al margen de las pautas del mercado" (Holloway en BRIANTE, 1988 : 13).

Sobre la primera muestra del Grupo Periferia, la crítica Laura Buccellato escribió : "Este 'cuarteto' enuncia la marginalidad, esquivando con humor crítico los burdos chauvinismos y asumiendo el legítimo pintoresquismo. Este operar desprejuiciado de la información que mezcla diferentes realidades, ironiza sobre nuestras dificultades e indica un avance certero hacia la libertad creativa, fuera de las modas para traspasar la frontera, esa de nuestra aceptación" (BUCCELLATO, 1987 : 48). Cada uno de los integrantes elaboraba su lenguaje pictórico con una distinta concepción sobre lo periférico. Suárez profundizaba su desarrollo del grotesco y de alguna manera parodiaba a quienes vivían cada vez más de aspiraciones vanas, tratando de escalar, "trepadores" que avanzaban sin importar el terreno donde pisasen.

Pablo Suárez, Trepando, 1987

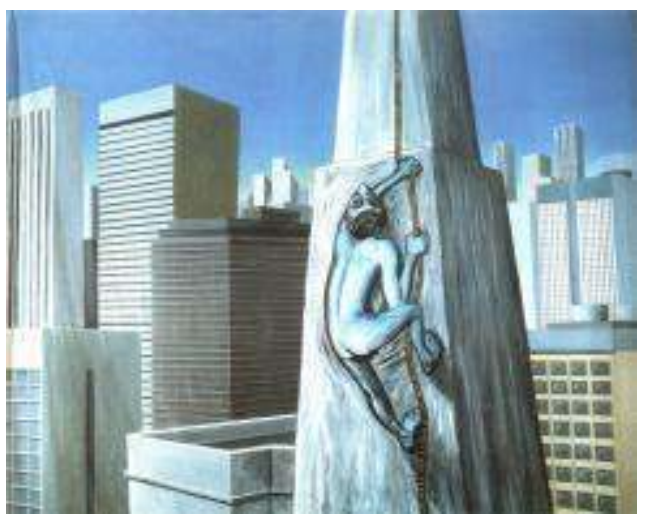

acrílico sobre tela, 243 × $298 \mathrm{~cm}$

Diferentes eran las figuras levitando de inspiraciones oníricas de Monzo 
Osvaldo Monzo, Lecho de rosas, 1987.

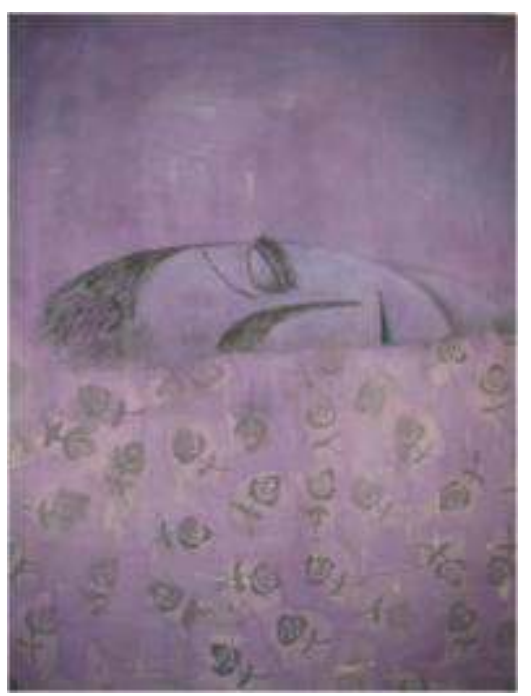

Por su parte, Prior encontraba un "exilio cultural en la tradición oriental" que él mismo inventaba, en la proximidad de Amalia Sato, por entonces su mujer de ascendencia japonesa. En ocasión de la participación en la primera exposición, Rearte presentó obras identificadas como Me duele el mate o Un grito argentino que, según lo registra Buccellato, argumentaban sobre "la banalización internacional de lo 'folk', desmitificando los populismos, en busca de lo popular para evitar los peligros de la masificación. Para esto satiriza el discurso sobre sí mismo con añorantes imágenes emblemáticas de la tradición criolla. Pone en jaque cualquier categorización conceptual."

En el catálogo Glusberg los presentaba, con su frase de rigor, como cuatro artistas de reconocida trayectoria que estuvieron inscriptos en "el fenómeno casi universal del neoexpresionismo o pintura salvaje para los alemanes, o transvanguardia para los italianos o nueva imagen para nosotros" (GLUSBERG, 1987). No obstante, apuntó ahora que transgredían todo lo anterior. "El proyecto actual de los cuatro artistas -aclaraba- es mostrar al mundo nuestra Periferia." Por otro lado, contradiciendo su enunciado inicial los describía como indiferentes a los estilos emanados de los centros internacionales. Y finalizaba: "En este contexto se inscribe la expectativa del grupo Periferia : la recurrencia a los elementos cotidianos $y$ el empleo de técnicas y materiales que aluden a una cultura local y marginal, con ciertos toques sutiles de kitsch. Una periferia que intenta trascender su ubicación geográfica para dialogar con sus pares de los centros internacionales. El arte y su metadiscurso crítico exigen una revisión de los modelos simplistas de comunicación que se extraen de los manuales, permitiendo la elaboración de un pensamiento que libere formas y contenidos, para que periferias y centros se confundan en lo prioritario : el hecho artístico."

38 La segunda muestra inauguró el 5 de mayo de 1988 también en las salas del CAYC. Monzo, Pierri, Prior y Suárez mostraron una serie de pinturas, dibujos, objetos e instalaciones. Registraron elocuentemente sus principios frente a la elaboración de imágenes disfrazándose de piratas. 
Fotografía de prensa de la exposición grupo Periferia : Pablo Suárez, Osvaldo Monzo, Duilio Pierri y Alfredo Prior.

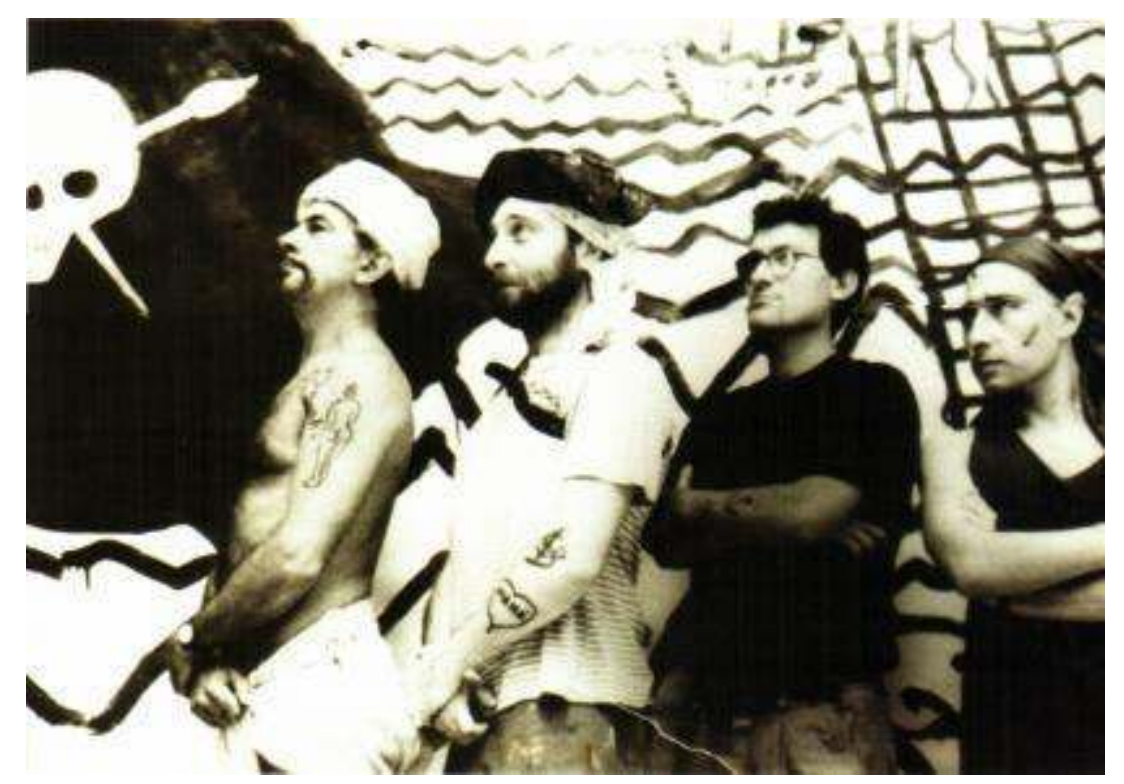

Por entonces en una entrevista Prior se refería al asunto de las citas y la apropiación como modalidades artísticas afirmado que: "Más que hablar de citas, de apropiaciones, yo hablaría de piratería, que es lo que nos corresponde desde nuestra situación de país periférico. Redactar hoy en día un manifiesto desde este emplazamiento marginal, sería redactar una Patente de Corso que nos habilite a saquear impunemente en toda la historia del arte." (PRIOR, 1988) Por otro lado, como grupo, sostenían: "Uno recibe y da, también de rebote. Lo hacemos a lo pirata porque, también como [Antonio] Berni, pensamos que todo lo que los que no son marginales usan, nos ha sido robado, es nuestro. Berni solía exagerar diciendo que toda la cultura de ellos, la del establishment, está construida con nuestro trabajo" (citado en BRIANTE, 1988: 13).

En esta ocasión Monzo presentaba obras a las que les pegaba brillantina y recubría los marcos de sus pinturas y objetos con caracoles. Estas piezas establecían una ruptura con sus obras anteriores y encaraban una poética cercana a la reflexión sobre los límites de lo decorativo que se acentuaría en la década de 1990. Prior "pirateaba" Déjeuner sur l'herbe de Edouard Manet para crear su Desayuno sobre las rocas en la antigua China mestizando las culturas oriental y occidental. Pierri ilustraba la letra de una canción del músico inglés Elvis Costello donde se mencionaba una mujer que trabajaba en un hotel argentino del Puerto Stanley en las islas Malvinas. Agregaba a las obras ciertos juegos de palabras como paráfrasis visuales. "Una pintada política que unía a Rosas y Rico, lo lleva a pintar un tipo con smoking (rico) y un ramo de rosas", describía Glusberg (1988). Suárez expuso un gran estuche en forma de concha de mar donde se recostaba desnudo y nacarado su personaje El Perla. 
Pablo Suárez, El perla. Retrato de un taxi-boy, 1988

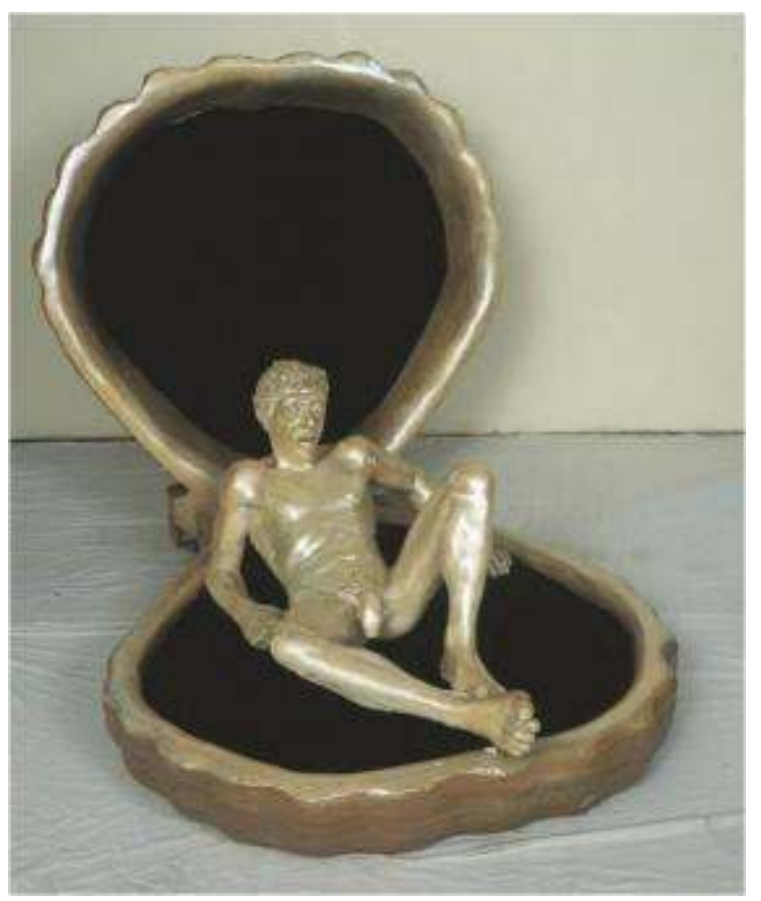

(recreada en 1992, epoxi sobre estructura de telgopor y pintada con esmalte de uñas perlado y tela, $102 \times 96 \times 135 \mathrm{~cm}$.)

La exposición se realizó después de una muestra de diez artistas argentinos en Francia organizada por el CAYC. Se trató de La Nouvelle Generation Argentine/88 que se llevó a cabo en la Galerie Beau Lázard de París. Fueron incluidos los cuatro artistas del Grupo Periferia junto a Cambre, Hernán Dompé, Fernando Fazzolari, Gustavo López Armentía, Eduardo Medici y Argentina Zamora (s/a, 1988: 2). El comunicado de prensa de la muestra del Grupo Periferia capitalizaba esta experiencia afirmando que los integrantes de la muestra habían recibido recientemente importantes elogios de la crítica francesa. Se informaba que los artistas habían despertado el interés de prestigiosas figuras de la crítica de Francia como Pierre Restany y el crítico del Nouvelle Observateur, Jean Dufresne. Este último había escrito: "Pierri conjuga los fastos de la paganidad clásica con los más revulsivos elementos del arte de nuestro siglo en un discurso vertido con una solvencia que, más allá de su ironía, jerarquiza su obra colocándola en un plano sólo accesible a un clásico contemporáneo. En la pintura de Osvaldo Monzo la recogida intimidad de sus imágenes se anima a través de un tratamiento, a la vez contenido y vibrante de la superficie. No podemos dejar de percibir al contemplar sus obras el halo mágico que sólo el arte esotérico hindú (piénsese en la pintura tántrica y en la saga del rey Naga), nos proporciona con tan decantada síntesis. [...] Suárez nos brinda una imagen desgarrada de Latinoamérica. Con énfasis sostenido no desmiente su raíz popular, si su áspera intencionalidad subversiva, todo ello vertido con brío de un pintor de raza." Por su parte, Restany había caracterizado a Suárez como "il dolce Caravaggio di periferia" y sobre Prior sostenía que "reúne en un planteo netamente pictórico las más sofisticadas sutilezas del arte conceptual a la vez que despliega un abanico de ritos perversos. Como un dulce veneno su obra conjuga la seducción del gusto con la letal negación del sentido" 8

42 La última presentación del Grupo Periferia como tal fue la exposición con la que inauguró un nuevo espacio en el circuito artístico de la ciudad de Buenos Aires que sería sumamente relevante en los años sucesivos. La muestra titulada Soberbia se presentó 
entre el 19 de septiembre y el 8 de octubre de 1988, en las salas del Centro Cultural del Instituto de Cooperación Iberoamericana (ICI), cuya subdirectora era Laura Buccellato. El catálogo cobró forma de gran afiche plegable diseñado por Luis Wells, donde el texto se componía con una especie de collage de imágenes de los cuatro integrantes. Fue escrito por el artista Roberto Jacoby y se trató menos de una interpretación de las obras que de "unos testimoniales brochazos biográficos recogidos al azar de mis andanzas bohemias" porque su autor consideraba que serían más útiles que una "parva de eruditas hermenéuticas teratológicas" (JACOBY, 1988). Si bien la exposición se había organizado en adhesión al XXII Congreso de la Asociación Internacional de Críticos de Arte y las X Jornadas de la Crítica, los artistas parecían aliarse en la prescindencia del discurso crítico que había caído paulatinamente en el descrédito debido a las marchas y contramarchas de la propia práctica.

\section{Consideraciones finales}

La escasa claridad teórica en la implantación y reiteración de las nociones de "Transvanguardia argentina" y la "Nueva Imagen argentina" las convirtieron en figuras tan maleables que perdieron significación y cualquier indicio de especificidad. La precariedad de las definiciones revela que se trató más de la adopción oportunista del carácter "nómade" -pregonado por Achille Bonito Oliva como la posibilidad de transitar libremente dentro de todos los territorios-, que de un trabajo reflexivo respecto de un lenguaje "más allá de" o "a través de" las vanguardias o la posibilidad de una nueva vanguardia en Argentina. Implicaron un límite interpretativo tanto para lo que no se incluyó en las exposiciones que se fundaban en ellas como para las propias producciones que abarcaba, debido a que no se verifica un juicio detenido sobre la imagen. Sobre el traslado al discurso de la crítica local de la terminología definida dentro de otras tradiciones, Marcelo Pacheco ha señalado que "El resultado casi natural es la profunda separación que surge entonces entre el discurso teórico -que adquiere autonomía propia y casi prescindente- $y$ el discurso visual -forzado a acomodarse en esquemas críticos ajenos $y$ autorreferentes. El fenómeno es particular, aunque casi endémico, ya que palabra e imagen comienzan a transitar caminos paralelos. [...] El problema no es la afirmación de un horizonte cultural internacional, no la participación en el proceso de globalización -ambos elementos de una realidad innegable- sino la adopción compulsiva e irreflexiva de los esquemas exteriores" (PACHECO, 1993: 164 y 166).

Es indiscutible que ciertos aspectos de las poéticas posmodernas internacionales eran compartidos por la producción vernácula; en especial, en lo que se refiere a las fusiones entre la "alta" y la "baja" cultura; al uso y resignificación de citas del amplísimo repertorio de la cultura visual y a los procedimientos paródicos. No obstante, la Transvanguardia como categoría generalizadora para el arte argentino ha resultado en un elemento de obliteración de sus sentidos críticos en la dinámica de la cultura visual durante la redemocratización. No permite dar cuenta de una serie de imágenes jalonadas entre la crisis de la representación dentro del propio lenguaje y la crisis en el afuera de su contexto de producción. Socava la actuación de artistas que encontraron en la retórica neoexpresionista el modo efectivo de vehiculizar la urgencia de manifestarse al término de la dictadura, sin descartar los procedimientos conceptuales y sirviéndose de ellos para la elaboración de sus obras. 
No obstante, en forma paralela a ese deterioro de los juicios críticos sobre el arte que la dinámica de los debates reconstruidos aquí exponía, comenzaba a ponerse en evidencia una creciente tendencia en la teoría del arte en América Latina. Una nueva masa crítica que dejaba atrás la vacuidad de análisis formales simplistas de las obras para trabajar sobre las condiciones sociales de su producción y expandir así sus posibilidades semánticas y de inscripción de la artes visuales en la nueva etapa histórica de la reapertura democrática que se abrió con el correr de los años de la década de 1980. Ya lo había advertido Néstor García Canclini en un artículo sobre la Bienal de San Pablo de 1979 y sobre un simposio que había reunido a críticos, historiadores y estetas latinoamericanos como Rita Eder, Marta Traba, Juan Acha, Mario Pedrosa, Aracy Amaral, Frederico de Morais, Roberto Pontual, Mirko Lauer, entre otros. "Al considerar el marco social de la producción artística, las condiciones históricas particulares de América Latina, y preocuparse no sólo por las obras sino por el público, los intermediarios, la inserción del artista en diferentes redes comunicativas, un nuevo horizonte conceptual -que ha venido construyéndose en México, Brasil, Argentina, Venezuela y Perú en los últimos años- se mostró en esta reunión como una alternativa de trabajo futuro" (GARCÍA CANCLINI, 1979: 36). En otras palabras, durante aquellos años comenzaron a generarse las condiciones de posibilidad para que la producción crítica desde y sobre América Latina desarrollara sus argumentos, ya no en términos reduccionistas y dicotómicos, sino apuntando a los desplazamientos y transgresiones de los modelos canónicos.

\section{BIBLIOGRAFÍA}

BENAVIDEZ BEDOYA A., "La transvanguardia en nuestro país bajo la supervisión de su creador: A. Bonito Oliva", in Arte Sur, v. 3, no 3, Buenos Aires, enero-marzo.

воNITo oliva A., “The Italian Trans-Avantgarde”, in Flash Art, 1979, no 92-93, octubre-noviembre, pp. 17-20.

BONITO olIVA A., La Transvanguardia Italiana - The Italian Trans-Avantgarde, Milán, Giancarlo Politi Editore, 1980.

BONITO OLIVA A., La trans-vanguardia, Buenos Aires, Rosenberg-Rita Editores, 1982.

BONITO oliVA A., Transavant-garde Internacional, Milano, Giancarlo Polito Editore, 1982.

Bonito oliva A., "La Transvanguardia italiana", in Arte Sur. Cuadernos de Artes Visuales, Buenos Aires, 1984, segundo trimestre, año 1, no 1,.

BRIANTE M., “Arte periférico. El raro mambo de los marginales”, Página 12, 1988, 10 de mayo, p. 13. BUCHLOH B., "Figures of Authority, Ciphers of Regression. Notes on the Return Representation in European Painting”, in October, 1981, no 16, Spring, pp. 39-68.

BucCellato L., “Grupo Periferia. Sí al pintoresquismo legítimo”, in Artinf, año 12, no 64/65, Buenos Aires, invierno, p. 48. 
ESCOBAR T., "Modernidades paralelas" in El arte fuera de sí Asunción, FONDEC - CAV/Museo del Barro, 2004.

ESPARTACO C., La anavanguardia, cat. exp., Buenos Aires, Estudio Giesso, 26 de agosto al 11 de septiembre 1982.

ESPARTACo C., "La Anavanguardia”, Artinf, 1982, año 6, nº 35/36, agosto-septiembre, p. 10.

ESPARTACO C., El estupor del arte, Buenos Aires, Ediciones de Arte Gaglianone, 1984.

ESTENSSORO M.E., “¿Para qué sirven los críticos?”, in El Porteño, año 1, n 1, Buenos Aires, 1982, enero, pp. 42-43.

GARCía CANCLINI N., “Uso artístico de los mitos o uso mítico del arte? A propósito de la Bienal de San Pablo", in Punto de Vista, 1979, año II, n 6, julio, pp. 35-38.

GIUFFRÉ H., "Transvanguadia, una estética de la traición. Lectura crítica de un texto de Bonito Oliva", in Arte Sur. Cuadernos de Artes Visuales, 1985, año 2, no 2, primer trimestre.

GLUSBERg J., “Un mismo lenguaje”, in Clarín, Buenos Aires, 20 de noviembre 1982.

GLUSBERG, "La nueva imagen en Latinoamérica", in Transavant-garde Internacional, Achille BONITO oLIVA, Milano, Giancarlo Polito Editore, 1982, pp. 291-301.

GLUSBERG, Grupo Periferia, cat. exp., Buenos Aires, Centro de Arte y Comunicación, 1987.

GLUSBERG, "Periferia, la realidad y los mitos", in Nueva presencia, no 568, Buenos Aires, 20 de mayo 1988.

GUASCH A.M. , "Transvanguardia y anacronismo: la visión italiana”, in El arte del siglo XX en sus exposiciones. 1945-1995, Barcelona, Ediciones del Serbal, 1997.

HABER A., “Transvanguardia, una estética de la traición. Lectura crítica de un texto de Bonito Oliva", in Arte Sur. Cuadernos de Artes Visuales, 1985, año 2, nº 2, primer trimestre.

JACOBY R., Soberbia, cat. exp., Buenos Aires, Centro Cultural del Instituto de Cooperación Iberomericana de Buenos Aires, 19 de septiembre al 8 de octubre 1988.

KATZENSTEIN I., “Una introducción a la obra de Enzo Cucchi”, cat. exp, Buenos Aires, Centro Cultural Recoleta, 10 de julio al 10 de agosto 1997.

LÓPEZ ANAYA J., "Jornadas de la crítica”, in Artinf, nº 43, Buenos Aires, 1983, noviembre-diciembre, p.14.

LÓPEZ ANAYA, "Los años ochenta en el arte argentino. El huracán posmoderno de los ochenta", in Arte al día, vol. 11, no 39, Buenos Aires, 1990, agosto, p. 33.

NOÉ, L.F., "Una mirada al arte argentino", in Cuadernos Hispanoamericanos, № 517-519 (La cultura argentina : de la dictadura a la democracia), 1993, julio-septiembre, p. 241.

PACHECO M., “Guillermo Kuitca : Inventario de un pintor”, in Un libro sobre Guillermo Kuitca, AA.VV., cat.exp., Valencia, IVAM-Amsterdam, Contemporary Art Foundation, 1993, pp. 161-198.

PACHECO, "La parodia y los juegos de la verdad", en Cantos Paralelos/ Parallel Cantoss : Experimental Art from Argentina, Mari CARMEN RAMírez (ed.), Archer M. Huntington Art Gallery, The University of Texas at Austin, 1999.

PACHECO, "Nuevos modelos de exposiciones de arte latinoamericano del siglo XXI: impacto y eficacia", in Circuitos latinoamericanos. Circuitos internacionales: interacción, roles y perspectivas, AA.VV., Buenos Aires, arteBA Fundación, 2005. 
PRIOR A. Alfredo Prior, "Prior : Páginas de artista", in Artinf, nº 70/71, Buenos Aires, invierno, 1988.

PRIOR, "Entrevista a Alfredo Prior por Leo Chiachio y Gabriela Francone", in Espacio Giesso, año 1, no 2, Buenos Aires, 1999, abril, p.4.

RENZI J.P., “Renzi. En el arte no hay progresos”, in Artinf, año 6, no 33-34, Buenos Aires, 1986, mayo-junio, p. 16.

(S.A), “Diez argentinos en París", in El cronista comercial, Buenos Aires, 11 de marzo, secc. OcioNegocio, 1988, p. 2.

(S.A) J.P., "Expone el Grupo Periferia. Tras elogios de la crítica francesa”, El cronista comercial, Buenos Aires, 20 de mayo 1988.

SHAW, E., Seis décadas de arte argentino, Buenos Aires, universidad Torcuato Di Tella, 1998.

SARLO, B., Una modernidad periférica. Buenos Aires 1920-1930, Buenos Aires, Nueva Visión, 1988.

SPERANZA, G., Guillermo Kuitca. Obras 1982-1998. Conversaciones con Graciela Speranza, Buenos Aires, Grupo Editorial Norma, 1998.

USUBIAGA V., "Between Regionalism and Internationalism : Definitions of Latin American Art at the 1985 São Paulo International Biennale" en Transnational Latin American Art from 1950 to the Present Day - 1st International Research Forum for Graduate Students and Emerging Scholars, University of Texas, Austin, 2010.

USUBIAGA V., Imágenes inestables. Artes visuales, dictadura y democracia en Buenos Aires, Buenos Aires, Edhasa, 2012.

LóPEZ ANAYA J., “Jornadas de la crítica”, en Artinf, n 43, Buenos Aires, noviembre-diciembre, 1983, p.14.

\section{NOTAS}

1. Sobre estos temas y un desarrollo mayor sobre los tratados aquí, véase el libro de mi autoría Imágenes inestables (USUBIAGA, 2012).

2. Entre los invitados extranjeros participaron también Ilse Henning y Adolph Opel de Austria ; Sheila Leirner y Carlos von Schmidt del Brasil ; Nelly Richard, Waldemar Sommer y Vittorio de Girolamo de Chile ; Gregory Battcock y Angiola Churchill de Estados Unidos ; Georges Boudaille y Marc Emery de Francia ; Christos Joachimides y Joseph Kleihues venidos de la República Federal Alemana y Ángel Kalenberg y María Luisa Torrens de Uruguay.

3. Valga como ejemplo el artículo de BUCHLOH, 1981.

4. Entrevista de la autora a Guillermo Kuitca, Buenos Aires, 9 de febrero de 2005.

5. Ibídem.

6. Al respecto véase el artículo de mi autoría "Between Regionalism and Internationalism: Definitions of Latin American Art at the 1985 São Paulo International Biennale" (USUBIAGA, 2010). La delegación de artistas argentinos fue una de las más numerosas en aquella bienal. Participaron : Luis Felipe Noé, Rómulo Macció, Ernesto Deira, Jorge de la Vega, Guillermo Kuitca, Ana Eckell, Pablo Suárez, Fernando Fazzolari, Armando Rearte, Juan Pablo Renzi, Alfredo Prior, Juan José Cambre, Duilio Pierri y Osvaldo Romberg.

7. Entrevista de la autora a Osvaldo Monzo, 19 de abril del 2007.

8. “Grupo Periferia en el CAYC, Comunicado de prensa. Archivo de Osvaldo Monzo. 


\section{RESÚMENES}

Centrado en los años ochenta del siglo XX este artículo se ocupa del análisis de las proyecciones tanto discursivas como expositivas construidas sobre las artes plásticas argentinas en los albores de la mentada globalización. A través de un recorrido por una serie de exposiciones y textos críticos que propiciaron acalorados debates se analiza la recepción de la Transvanguardia y las tendencias neoexpresionistas en el Cono Sur. El trabajo reconstruye la trama cultural de un momento clave para la reapertura y el fortalecimiento de una red de contactos artísticos e intelectuales que en forma activa permitió desestabilizar concepciones sobre el arte argentino y latinoamericano y propiciar la elaboración de una nueva historiografía sobre América Latina al que este artículo busca contribuir.

Centré sur les années 1980, cet article s'intéresse à l'analyse des discours et expositions sur les arts plastiques argentins à l'aube de la globalisation. Au travers de toute une série d'expositions et de textes critiques qui ont suscité des débats enflammés, nous analyserons la réception de la Transvanguardia et des tendances néo-expressionnistes dans le Cône sud. Ce travail cherche à restituer la trame culturelle des années postérieures à la dictature militaire, qui furent un moment-clé pour la réouverture et la consolidation d'un réseau de contacts artistiques et intellectuels. Ce processus a permis de remettre en question certaines conceptions de l'art argentin et sud-américain, favorisant l'émergence d'une nouvelle historiographie sur l'Amérique latine, à laquelle cet article cherche à contribuer.

\section{ÍNDICE}

Mots-clés: arts plastiques, Argentine, années 1980, transvanguardia, critique d'art, expositions, biennale de São Paulo

Palabras claves: artes plásticas, Argentina, transvanguardia, crítica, exposiciones, bienal San Pablo, década de 1980

\section{AUTOR}

\section{VIVIANA USUBIAGA}

Viviana Usubiaga es doctora en Historia y Teoría de las Artes por la Universidad de Buenos Aires. Investigadora del CONICET. Docente de grado en UBA y profesora de posgrado en las universidades nacionales de San Martín y Tres de Febrero. Editora de la revista "Blanco sobre blanco. Miradas y lecturas sobre artes visuales". Miembro de la comisión directiva del Centro Argentino de Investigadores de Arte. Autora de "Imágenes inestables. Artes visuales, dictadura y democracia en Buenos Aires " (Edhasa, 2012).

CONICET / UBA / IDAES-UNSAM /UNTREF - Email: vivusubiaga[at]uolsinectis.com.ar 